Soil Science and Agricultural Engineering

http:/www.journals.zu.edu.eg/journalDisplay.aspx?Journalld=1\&queryType=Master

\title{
PERFORMANCE EVALUATION OF A SMALL AC/DC SOLAR WATER PUMPING SYSTEM FOR ROOF CULTIVATION
}

\author{
Samar A. Hassan*, M.K. Abd El-Wahab, A.M. El-Shal and W.E. Abd Allah \\ Agric. Eng. Dept., Fac. Agric., Zagazig Univ., Egypt
}

\section{Received: 30/12/2019 ; Accepted: 23/01/2019}

\begin{abstract}
Solar water pumping for irrigation and drinking purposes is considered one of the most recently power system needed. The most important usage of solar pumping systems is to irrigate the agricultural lands to help farmers instead of using electrical or fuel system that take a lot of time, high cost, effort and much losses. In this research, the performance evaluation of a mini water pump (5 Watt) powered by small solar photovoltaic (PV) panel (10 Watt) was investigated to supply the needed water for irrigating roof cultivation units. The experiments were carried out at Faculty of Agriculture, Zagazig University, Sharkia Governorate, Egypt (Latitude $30.5^{\circ}$ - Longitude $31.5^{\circ}$ ) in winter and summer seasons of 2018. Two solar pumping systems were evaluated; DC solar pumping system (DSPS) and AC solar pumping system (ASPS) under different operating parameters of PV panel tilt angles $\left(15^{\circ}, 30^{\circ}, 45^{\circ}, 60^{\circ}\right.$ and $\left.75^{\circ}\right)$, solar radiation hours during daylight (9:00 to 15:00) and pumping heads $(0,0.5,1$ and $1.5 \mathrm{~m})$. All parameters were evaluated by determinations of pumping discharge, hydraulic energy, pump efficiency and cost. The obtained results revealed that, the best PV panel tilt angle for Zagazig region was $45^{\circ}$ and $30^{\circ}$ in winter and summer, respectively. Discharges and pumping efficiencies of ASPS were higher than DSPS. The optimum pumping conditions were 0.25 and $1 \mathrm{~m}$ of pumping heads with $220 \mathrm{l} / \mathrm{hr}$., and ( $83 \mathrm{l} / \mathrm{hr}$., for winter, $88 \mathrm{l} / \mathrm{hr}$., for summer) of pumping discharge for ASPS and DSPS, respectively. Pumping costs of one cubic meter of water by DSPS at pumping heads of $0,0.5,1$ and $1.5 \mathrm{~m}$ were $(0.16,0.17,0.19$ and $0.21 \mathrm{LE})$ and $(0.15,0.17,0.19$ and $0.21 \mathrm{LE}$ ), during winter and summer seasons, respectively. While pumping costs of one cubic meter of water using ASPS were about $0.22,0.45,1.23$ and $7.11 \mathrm{LE} / \mathrm{m}^{3}$ at the same heads, respectively. So, a small size of solar PV power system can be efficiently supply irrigation water for roof cultivation units.
\end{abstract}

Key words: PV, DC solar pumping system (DSPS), AC solar pumping water (ASPS), tilt angle, discharge, hydraulic energy, pump efficiency, cost.

\section{INTRODUCTION}

In Egypt, although the exerted huge efforts of government to face the challenges of lack access to grid electricity due to the inability of current producing to catch up with the rapidly increase in population (Khattab et al., 2011), therefore, depending on electric power source in remote and developing rural areas suffers many problems. So, it became necessary to utilize the renewable energy (RE) sources to produce the needed requirements of energy for developing those communities. Whereas, the cost of producing electricity from RE sources is lower than conventional electricity because of savings in the construction of infrastructure and cables extends. Also, high and continuous rapid in diesel prices and transporting costs in addition to its environmental problems make that nonreliable source of energy. Therefore solar PV is considered one of fastest growing RE technologies in the world. This is due to its simplicity installation, flexibility size, low operation and maintenance cost, environmentally friendly because there is no harmful greenhouse gas emission from it (Said et al., 2017). Additionally, solar PV panels are easy to install on rooftops, producing no noise, having no

\footnotetext{
* Corresponding author: Tel. : +201002466331

E-mail address: samarhassan92@hotmail.com
} 
moving parts and depending on solar energy which freely supplied by nature and available anywhere there are sunlight. Egypt is one of the largest potentials of solar energy applications in the world. It locates in the World Sunbelt area and enjoys 9-11 hr., of daily sunshine with annual normal direct solar energy of 2000-3200 $\mathrm{kWh} / \mathrm{m}^{2}$. Egypt's present energy strategy encouraged and intended to increase the share of RE to $20 \%$ of Egypt's energy balanced mix by 2022 (NREA, 2011). So, and according to the present national plan of solar power is to install 3500 MW by the year 2027; including 700 MW of PV (NREA, 2013).

In this context, supplying energy for agricultural applications particularly, water pumping for irrigation or drinking purposes requires alternative, clean, reliable and available low-cost systems instead of using diesel generators or electric motors. One of the most advantages of the solar PV water pumping system was the most less cost system over the years in comparison to diesel, gasoline even electricity pumps. Additionally, operating cost is very low because it doesn't require fuel. It has a very low maintenance cost if the system has well set up, only it requires a simple periodic maintenance for cleaning of panels. The lower cost of solar pumping system will be selected by all farmers in the future because not only, the cost of PV panel decreased by over $80 \%$ in the last 10 years but also, the cost of diesel or gasoline increased by over 250\% (Foster and Cota, 2014), Hence there was a comparison between two systems the first was PV water pumping system while the second was diesel water pumping system by the life cycle cost (LCC) analysis resulted that the first system was the more economical choice (Narale et al., 2013). On other hand the PV water pumping system was obtainable as the commercial product, had proved efficiency, require few expert manpower once when operated, and maintenance cost was much low and cheap (Yingdong et al., 2011). Moreover, solar PV is characterized as a renewable resource doesn't produce any harmful contaminants to the surrounding environment vice versa in the case of fossil fuels which produce harmful gases (Guiqiang et al., 2017). Actually, it is found that, one of the main functions of PV water pumping systems is to decrease ecological effects as a result of the extravagant use of fuels, especially in irrigation (Gopal et al., 2013).
Noting that, the water pumping using solar PV was one of the best systems for irrigation (Shinde and Wandre, 2015).

Singh and Mishra (2015) designed a mini unit that consisted of water tank with size of $(400 \times 400 \times 300) \mathrm{mm}$, pump shaft coupling, DC motor voltage of $24 \mathrm{~V}$, current of $14 \mathrm{~A}$ and power of $250 \mathrm{~W}$, PV $8 \mathrm{~A} / 21.6 \mathrm{~V} / 150 \mathrm{~W}$ (Gad, 2009) investigated a $D C$ water pump working by $\mathrm{PV}$ in Egypt. The pumping discharges were 24.06, 21.47 and 12.12 1/day in summer, equinoxes, and winter, respectively, and the PV efficiencies were 13.86 and $13.91 \%$ in winter and summer, respectively. The dynamic head of the pump impacts the performance of this system. In hours of the early morning or near to hours of evening time, the solar radiation was lower so the efficiency of the system was high when used a small of the head. Reciprocally in the hours at noon, the radiation was highest, and then the system using a big head was the highest efficiency. The max electricity efficiency from the PV panel is influenced by the tilt angle (Benghanem et al., 2014). Hamidat and Benyoucef (2008) designed a DC pumping water system and $\mathrm{AC}$ pumping water system. The two systems of PV pumping were first consisting of centrifugal pump and $\mathrm{AC}$ engine and second system consist of positive displacement pump and DC engine which have been tested with result the DC system was the best performance comparatively. Also, (Chandel et al., 2015) reported that, the DC pump solar system without storage power in the battery was still low cost, easy and reliable to used small irrigation system with the sprinkler or drinking water supplies.

In this context, solar water pumping has been focused whereas; it can be directly converted solar energy into electricity for water pumping using PV solar panels. Whereas, it can produce electricity for either storing in batteries or using directly in DC motors or converting into AC by using inverter and then connecting water pumps. So, as a contribution for sharing and using PV systems in small applications to participate in achieving the national plan of solar power in Egypt, this paper aims to study and evaluate the performance of small PV water pumping system (5 Watt of pump, 10 Watt of PV) in summer and winter seasons to supply the needed irrigation water for roof cultivation units. 


\section{MATERIALS AND METHODS}

The investigation was carried out during winter and summer seasons of 2018 at Faculty of Agriculture, Zagazig University, Zagazig, Sharkia Governorate, Egypt to evaluate technically and economically a small installation of solar PV water pumping system suit to roof cultivation units under solar Egyptian radiation conditions in Sharkia Governorate, Zagazig District.

\section{Materials}

\section{Solar PV water pumping system}

A solar PV water pumping system was installed as shown in Fig. 1. It consists of:

\section{Solar PV panel}

A 10 Watt solar PV panel (model of STPV36CELLS A Grade), is a packaged type of polycrystalline connected assembly of crystalline silicon photovoltaic cells, was used as a DC output power source for operating of water pump. It has $0.56 \mathrm{~A}_{\mathrm{mp}} / 17.9 \mathrm{~V}_{\mathrm{mp}}$ and $0.62 \mathrm{~A}_{\mathrm{sc}}$ $/ 21.5 \mathrm{~V}_{\mathrm{oc}}$ with dimensions of $310 \times 217 \times 17 \mathrm{~mm}$. Solar PV panels use light energy of the sun to generate electricity through the photovoltaic effect.

\section{Pumps}

Two pumps with the same power were evaluated: the first one was a DC pump (with specifications of: 5 Watt of power size, dimensions of $90 \times 40 \times 35 \mathrm{~mm}$ and 0.5 $0.7 \mathrm{~A} / 12 \mathrm{~V}$ ); the second was an AC pump (with specifications of: 5 Watt of power size, operating voltage of $220-240 \mathrm{~V}$ and $50 \mathrm{~Hz}$ of frequency).

\section{Voltage regulator}

It was used to stabilize the outside voltage of the solar PV panel to 12 volt to operate pumps. This worked to protect pumps from any increased voltage difference that can cause damage of pumps. The maximum ampere was 5A.

\section{Battery}

A battery (model of UNKOR MxVolta) was used with specifications of 12V/7 Ahr., $20 \mathrm{hr}$., to store the produced electrical energy by the PV panel.

\section{Charger controller}

The charge controller was used in PV solar pumping water system if was used the battery so as to keep the battery from the overcharging. The model used was (ISO 9001) with rated voltage of $12 / 24 \mathrm{~V}$ and the current of $20 \mathrm{~A}$.

\section{Invertor}

The inverter was used to convert direct current (DC) to alternating current (AC) by the capacity of $500 \mathrm{~W}$ and the input voltage was 12 $\mathrm{V}$ and the output voltage was $220 \mathrm{~V}$. The model used was (HOPSON V500).

\section{Roof cultivation units}

Four basins of wood with dimensions of 150 $\times 100 \mathrm{~cm}$ were used on different heights of 0 , $0.5,1$ and $1.5 \mathrm{~m}$ from roof level to test pumping system on these heads, as shown in Fig. 2. The basins had been cultivated with Thyme (Thymus Vulgaris). It is a medicinal and aromatic plant. It was cultivated in two rows $(50 \mathrm{~cm}$ in length and each row containing 5 plants for one basin). It has many uses like in cooking, medicine to treat gastrointestinal diseases and field of cosmetics. The medical part used by Thyme is the flowering branches and leaves. It was generally common in the countries of the Mediterranean basin, which is found in all types of land, preferably sandy and yellow.

\section{Methods}

Experiments were conducted to evaluate two installations (as shown in Fig. 3) of solar PV water pumping systems during winter and summer seasons of 2018 year; DC solar pumping system (DSPS) and AC solar pumping system (ASPS). Each treatment was for three consequently days for replicates. Two systems were 10 Watt of PV power and 5 Watt of pump power. They were evaluated by determinations of PV efficiency, pumping discharge, hydraulic energy, pump efficiency and cost under the following conditions:

Different PV tilt angles $\left(15^{\circ}, 30^{\circ}, 45^{\circ}, 60^{\circ}\right.$ and $\left.75^{\circ}\right)$

Different daylight hours (from 9:00 to 15:00)

Different pumping heads $(0,0.5,1$ and $1.5 \mathrm{~m})$ 
68

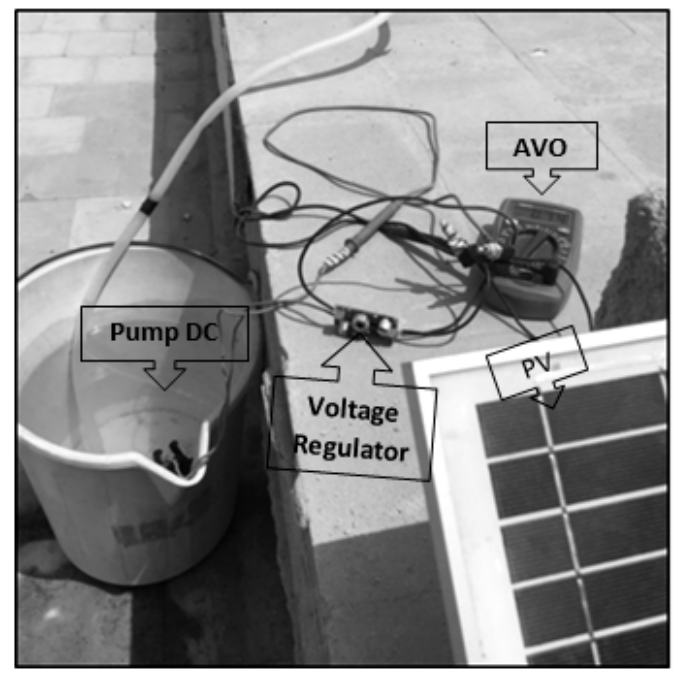

Hassan, et al.

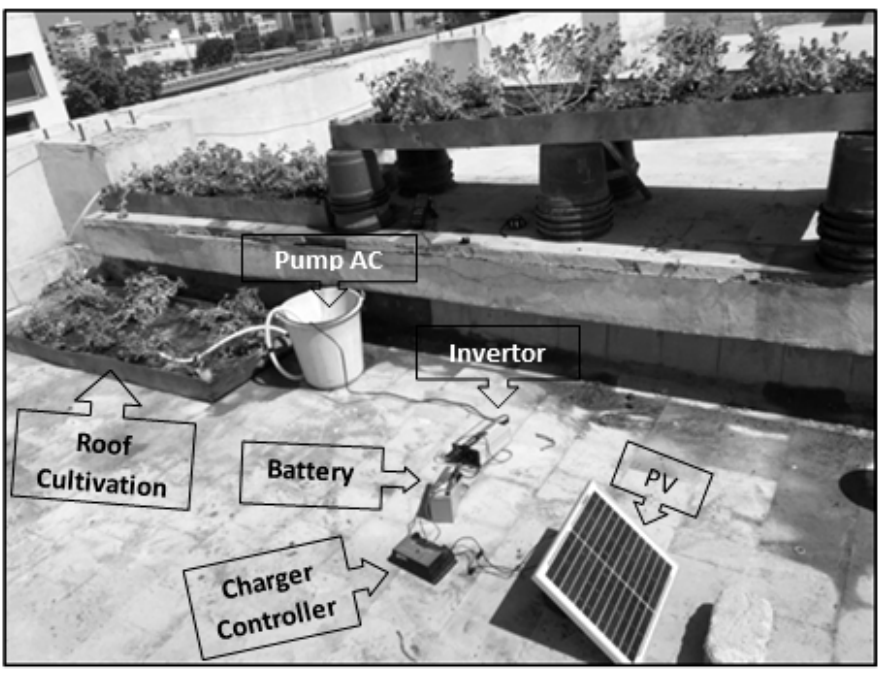

Fig. 1. The solar PV water pumping system

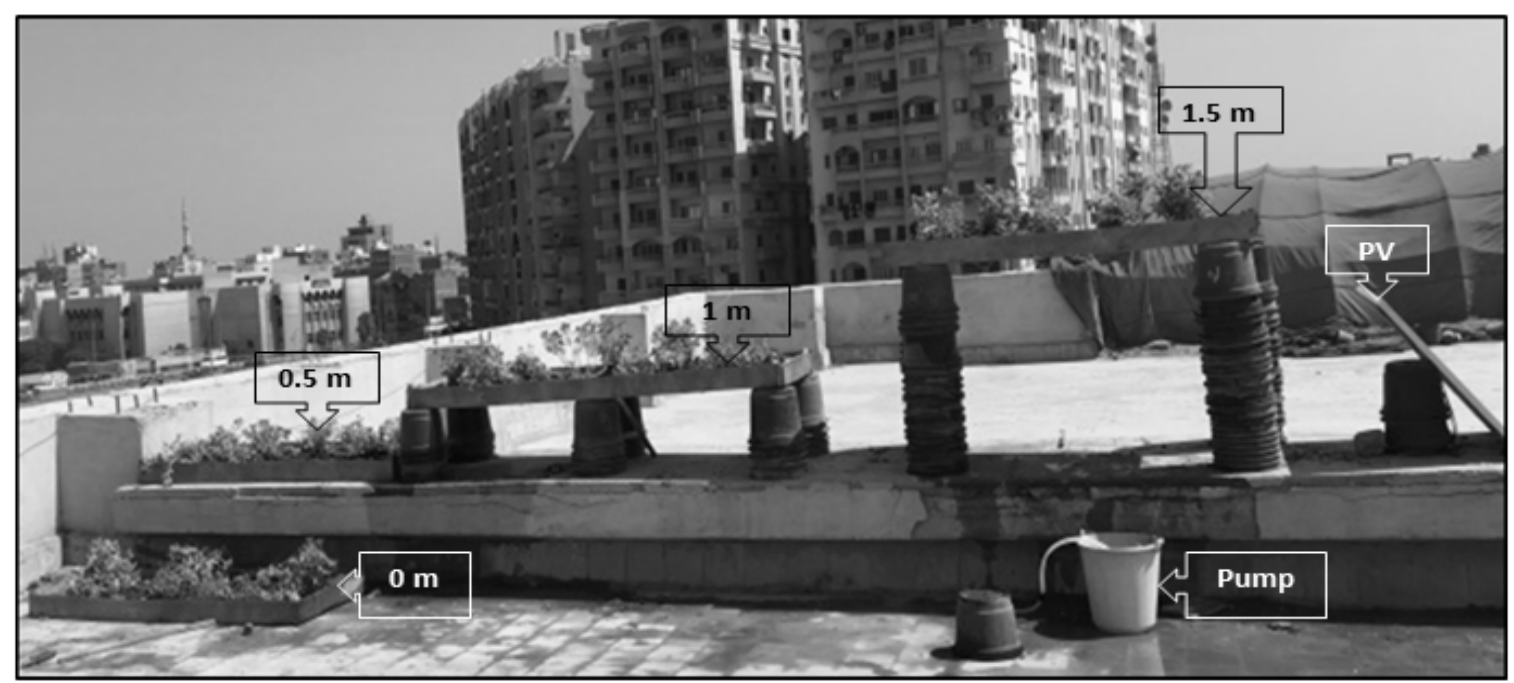

Fig. 2. A photo of roof cultivation units

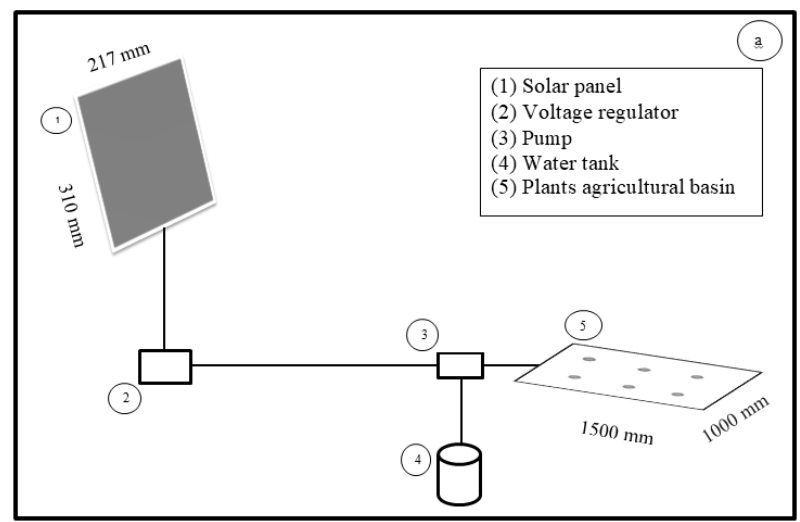

Unit pumping DC system

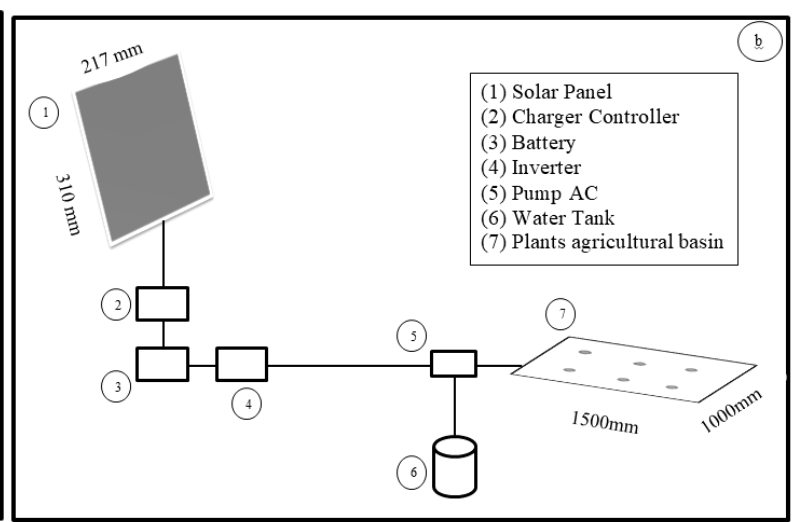

Unit pumping AC system

Fig. 3. Installation of (a) DSPS, (b) ASPS 


\section{Orientation of PV panel}

A 10 watt PV was oriented to face exactly the South direction (as shown in Fig. 4) with different tilt angle $(\alpha)$ to choose the best angle for winter and summer seasons to optimum the PV efficiency of collecting and converting solar radiation to electricity by indicated output ampere and voltage measurements.

\section{Measurements and Determinations}

\section{Solar radiation}

The solar radiation intensity during operating daylight hours (9:00 to 15:00) was measured using a solari-meter (Model of TES-132, TENMARS, Taiwan), with measuring range of $0-2000 \mathrm{~W} / \mathrm{m}^{2}$, resolution of $0.1 \mathrm{~W} / \mathrm{m}^{2}$ and accuracy of $\pm 10 \mathrm{~W} / \mathrm{m}^{2}$.

\section{Volt and amber}

Digital multimeter (Model of UT33C) was used to measure the output current and voltage for PV and pump. All ranges could be selected by a single rotary switch which set both the function and the range value. The DC Voltage ranges are: $200 \mathrm{mV}, 2000 \mathrm{mV}, 20 \mathrm{~V}, 200 \mathrm{~V}$ and $500 \mathrm{~V}$. While the current measurement was 4 positions on the rotary switch: $20 \mathrm{~mA}, 200 \mathrm{~mA}$, $2000 \mathrm{~mA}$ and 10A. And it was used of $20 \mathrm{~V}$ and $10 \mathrm{~A}$ to measurement volt and ampere. Fig. 5 showed the connecting methods for measuring operations in both DSPS and ASPS installations. Whereas, using the multimeter in AC circuit was with battery, inverter and AC pump, while at DC circuit was with PV panel, voltage regulator and DC pump.

\section{Efficiency of PV panel}

The efficiency of PV panel to calculate the gained energy from the incident solar energy for each tilt angle for winter and summer seasons was determined using the following equation:

$\eta_{\mathrm{PV}}=\frac{\mathrm{I}_{\mathrm{PV}} \times \tilde{\mathrm{V}}_{\mathrm{PV}}}{\mathrm{SR} \times \mathrm{A}_{\mathrm{PV}}} \times 100($ Chandel et al., 2015)

Where:

$\eta_{\mathrm{PV}}=\mathrm{PV}$ efficiency (\%)

$\mathrm{I}_{\mathrm{PV}}=$ Output current of PV (Ampere)

$\hat{\vartheta}_{p V}=$ Voltage output PV (Volt)
$\mathrm{SR}=$ Average solar radiation intensity $\left(\mathrm{W} / \mathrm{m}^{2}\right)$

$\mathrm{A}_{\mathrm{PV}}=$ Surface area of $\mathrm{PV}$ panel $\left(\mathrm{m}^{2}\right)$

\section{Electrical energy}

The required electrical energy for operating the pump was calculated as the following equation:

Where:

$$
\mathrm{E}_{\mathrm{e}}=\mathrm{I} \cdot \mathrm{V} \cdot \operatorname{Cos} \theta
$$

$\mathrm{E}_{\mathrm{e}}=$ Electrical energy of the pump (Wh)

$\mathrm{I}=$ Current intensity (Ampere)

$\mathrm{V}=$ Voltage $($ Volt $)$

$\operatorname{Cos} \theta=$ power factor (0.7) (Umran, 2015)

\section{Hydraulic energy}

The output hydraulic energy of pump was calculated as the following equation:

$\mathbf{E}_{\mathrm{h}}=\frac{\rho \times \mathbf{g} \times \mathbf{0 \times \mathrm { t } \times \mathrm { TDH }}}{3600}$

(Chandel et al., 2015)

Where:

$E_{h}=$ Hydraulic energy of pump (Wh)

$\rho=$ The water density $\left(1000 \mathrm{~kg} / \mathrm{m}^{3}\right)$

$\mathrm{g}=$ The gravity acceleration $\left(9.81 \mathrm{~m} / \mathrm{s}^{2}\right)$

$\mathrm{TDH}=$ The total dynamic head of pump (m), it concludes the head of pump and the head required to overcome friction loss $\left(\mathrm{h}_{\mathrm{f}}\right.$, as following the equation:

$\mathrm{TDH}=\mathrm{H}+\mathrm{h}_{\mathrm{f}}$

Where:

$\mathrm{h}_{\mathrm{f}}=$ required head to overcome friction loss taken $(20 \%$ of $\mathrm{H})$.

$\mathrm{Q}=$ the discharge of pump $\left(\mathrm{m}^{3} / \mathrm{s}\right)$, The pump discharge was measured using a stopwatch and a scale pail of $18 \mathrm{~L}$ of plastic and the volume of water out of the pump was calculated in 5 minutes for each replicate then calculated as following equation:

$$
\mathrm{Q}=\frac{\mathrm{V}}{\mathrm{t}}
$$

Where:

$\mathrm{Q}=$ Discharge of pump $\left(\mathrm{m}^{3} / \mathrm{s}\right)$

$\mathrm{V}=$ Volume of water $\left(\mathrm{m}^{3}\right)$

$\mathrm{t}=$ Time (sec.) 


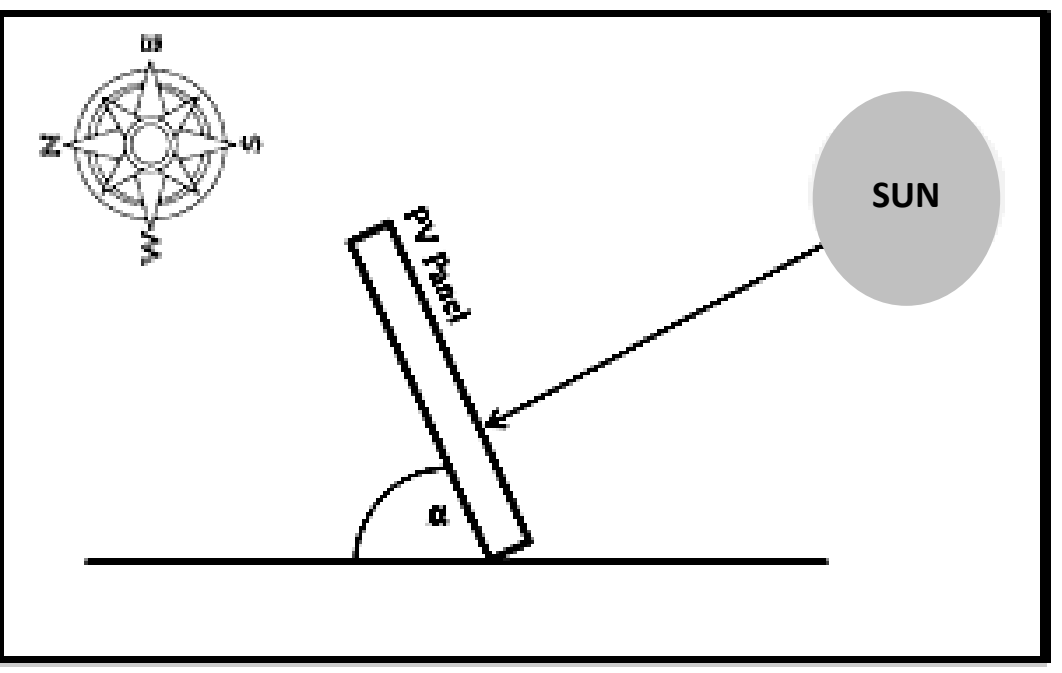

Fig. 4. Tilt angle and the orientation of PV panel

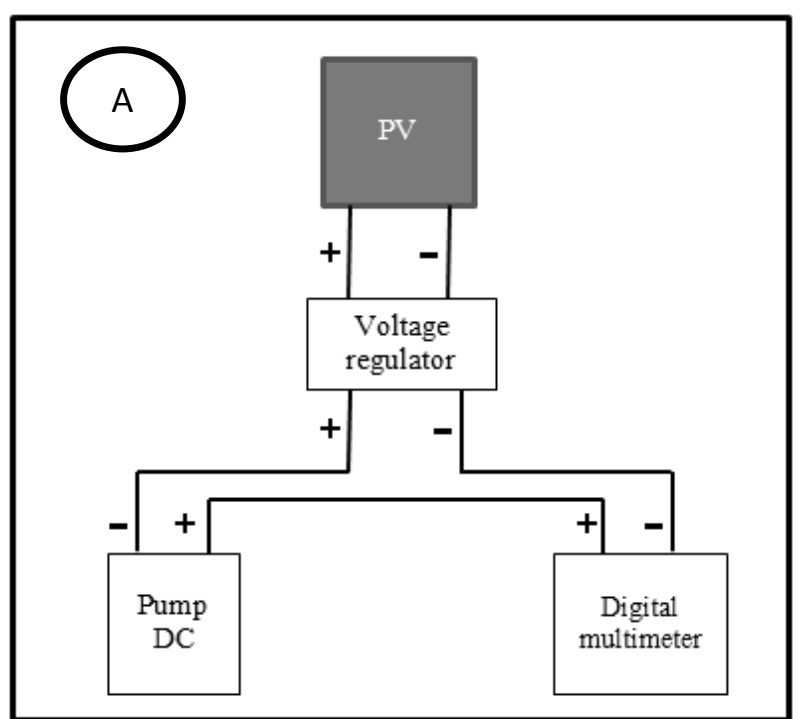

(a): DSPS

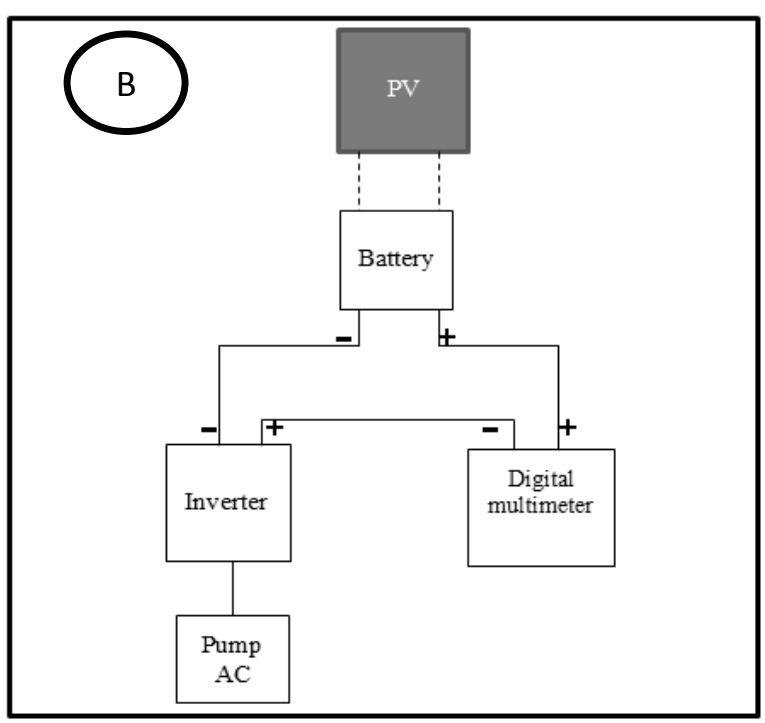

(b): ASPS

Fig. 5: Measuring methods of voltage and ampere in DC and AC systems

\section{Total efficiency of pump}

The total efficiency of the pump was calculated as the following equation:

$\eta_{t p}=\frac{\frac{E h}{\overline{0.4}}}{E e} \times 100 \quad$ (Benghanem et al., 2014)

Where:

$\eta_{\text {tp }}=$ Total efficiency of the pump (\%)

$0.4=$ Factor of transmitted power for small pumps (Frederick, 2010)

\section{Life cycle cost (LCC) analysis of DSPS and ASPS}

The life cycle cost analysis was carried out for the DSPS and ASPS power systems assuming useful life of 20 years for PV panel system and ten years life for battery. The capital cost for two system is given in Table $1(1 \$=$ 17.8 EGP. This cost analysis was estimated in the following LCC analysis according to (Chel et al., 2009). 
Table 1. The capital cost of DSPS and ASPS

\begin{tabular}{lcc}
\hline Components of system & \multicolumn{2}{c}{ Cost (LE) } \\
\cline { 2 - 3 } & DSPS & ASPS \\
\hline PV & 175 & 175 \\
Cables & 35 & 35 \\
Voltage regulator & 65 & - \\
DC Pump & 100 & - \\
AC Pump & - & 50 \\
Battery & - & 390 \\
Inverter & - & 300 \\
Charge controller & - & 400 \\
Total & $\mathbf{3 7 5}$ & $\mathbf{1 3 5 0}$ \\
\hline
\end{tabular}

Present maintenance cost

Where:

$$
\mathbf{P}_{\mathrm{M}}=\mathrm{C}_{\mathrm{M}}\left[\frac{\left((\mathbf{1}+\mathbf{i})^{20}-\mathbf{1}\right)}{\left(\mathbf{i} \times(\mathbf{1}+\mathbf{i})^{20}\right)}\right]
$$

$\mathrm{P}_{\mathrm{M}}=$ Present maintenance cost (EGP).

$\mathrm{C}_{\mathrm{M}}=$ Annual maintenance and repairs cost (taken $2 \%$ of capital cost).

$\mathrm{i}=$ Interest rate (taken 10\%).

\section{Net present cost}

Where:

$$
\mathbf{P}_{\mathrm{Net}}=\mathbf{P}_{\mathrm{i}}+\mathbf{P}_{\mathrm{M}}+\left[\frac{\mathrm{C}_{\mathrm{B}+\mathrm{P}}}{(1+\mathrm{i})^{10}}\right]-\left[\frac{\mathrm{s}}{(1+\mathrm{i})^{20}}\right]
$$

$\mathrm{P}_{\mathrm{Net}}=$ Net present cost for PV (EGP).

$\mathrm{P}_{\mathrm{i}}=$ Capital cost (EGP).

$\mathrm{C}_{\mathrm{B}+\mathrm{P}}=$ Battery and pump cost (EGP).

$\mathrm{S}=$ Salvage value of system at the end 20 years (taken $15 \%$ of capital cost) (EGP).

\section{Annualized cost}

Where:

$$
A_{A}=P_{\text {Net }}\left[\frac{\left(\mathbf{i} \times(1+i)^{20}\right)}{\left((1+i)^{20}-1\right)}\right]
$$

$\mathrm{A}_{\mathrm{A}}=$ Annualized cost of system (EGP).

Cost per unit of electricity generated

$$
\mathrm{C}=\frac{\mathbf{A}_{\mathrm{A}}}{\mathbf{U}}
$$

Where:

$\mathrm{C}=$ Cost per unit of electricity generated by $\mathrm{PV}$ (EGP/kWh).

$\mathrm{U}=$ Total annual electrical energy used from PV (kWh/year).

\section{Specific (Criterion) cost}

Criterion cost of pumping one cubic meter of water by two systems (DSPS and ASPS) was calculated in $\left(\mathrm{LE} / \mathrm{m}^{3}\right)$, as the following equation:

$$
\mathbf{C}_{\mathrm{V}}=\frac{\mathbf{C}}{\mathbf{V}_{\mathrm{E}}}
$$

Where:

$\mathrm{C}_{\mathrm{V}}=$ Criterion cost of pumping $1 \mathrm{~m}^{3}$ of water $\left(\mathrm{LE} / \mathrm{m}^{3}\right)$.

$\mathrm{V}_{\mathrm{E}}=$ Pump productivity (volume of pumping water per one $\mathrm{kWh}$ of electrical energy from $\mathrm{PV})\left(\mathrm{m}^{3} / \mathrm{kWhr}\right.$.).

\section{Pump productivity}

$$
V_{E}=\frac{Q}{E p}
$$

Where:

$E_{p}=$ Required electrical energy for one hour of pumping $(\mathrm{kWh} / \mathrm{hr}$.)

$\mathrm{Q}=$ Discharge of pumping $\left(\mathrm{m}^{3} / \mathrm{hr}\right.$.) 


\section{RESULTS AND DISCUSSION}

\section{Effect of Tilt Angle on PV Efficiency}

The obtained results of PV efficiencies at different tilt angles during day light from 9:00 to 15:00 are shown in Fig. 6. The results showed that, in general, the output ampere values of the PV panel as well as the PV efficiencies are affected majority by the tilt angle and orientation of PV panel. This is due to the proportional relation of incident solar energy on PV panel and the output power (ampere and volt). Whereas tilt angle as a function of latitude is an important parameter affecting the orientation of incident and reflected solar radiation into/out of panel surface. Average solar radiation intensity increased gradually from 9:00 hour and reached to the peak at 11:00 to $13: 00$ hour then decreased to $15: 00$ hour.

In winter (28/1/2018), PV panel efficiencies increased from $15^{\circ}$ until reached to the peak at $45^{\circ}$ then decreased slightly until to $75^{\circ}$ (in Egypt, latitude of $30.5^{\circ}$ and longitude $31.5^{\circ}$ ). At average and maximum solar radiation intensity of $423,525 \mathrm{~W} / \mathrm{m}^{2}$, respectively, the average daily PV efficiency was 28.4, 31.8, 36.9, 32.6 and $30.7 \%$ for tilt angles of $15^{\circ}, 30^{\circ}, 45^{\circ}, 60^{\circ}$ and $75^{\circ}$, respectively. This because the incident sunbeam angle with the vertical plane is high, so increase of tilt angle led to increase the output power of PV panel as a function of gained solar energy till reach $45^{\circ}$. The $45^{\circ}$ tilt angle of PV panel was the best angle. Higher or lower than angle of $45^{\circ}$ led to reduce the normal solar radiation on the panel surface and increase the reflected solar radiation.

While in summer (29/7/2018), vice versa $\mathrm{PV}$ efficiencies increased by reducing the tilt angle because the lower incident angle of solar radiation and perpendicularity of sunlight during most daylight hours. The $30^{\circ}$ tilt angle of PV panel was the best angle. Whereas, at average and maximum solar radiation intensity of 810 , $891 \mathrm{~W} / \mathrm{m}^{2}$, respectively, the average daily PV efficiency was 18.1, 21.3, 17.5, 15.6 and $14.9 \%$ for tilt angles of $15^{\circ}, 30^{\circ}, 45^{\circ}, 60^{\circ}$ and $75^{\circ}$, respectively.

Finally, it should be noticed that, values of $\mathrm{PV}$ efficiencies in summer compared to winter season was reduced. This is due to the great impacts of solar radiation changes and temperature levels on PV panel power output and its efficiency. Additionally, high temperature levels affect negatively the PV efficiency whereas there is an inverse proportion between temperature and panel power. Therefore, the PV panel power decreases when the ambient temperature increases. So, the PV panel was tilted with angle of $45^{\circ}$ and $30^{\circ}$ for winter and summer, respectively for all treatments of pumping evaluation.

\section{Pumping Evaluation of DSPS}

The results of pumping discharges at different heads and solar radiation variations during daylight from 9:00 to 15:00 for three days in winter and summer seasons were shown in Figs. 7 and 8, respectively. The obtained results showed that, in general, the discharge of pump in head $0 \mathrm{~m}$ is the highest one and by increasing the head until to $1.5 \mathrm{~m}$, the discharge decreased. Where the discharge is inversely proportional to the head of pumping. Also, the results revealed that, the discharge as well as the solar radiation increased gradually from 9:00 hour and reached to the peak at 11:00 to 13:00 hour then decreased to 15:00 hour.

In winter, the average daily pumping discharges for three days were $100.8,93.2,83$ and $77.51 / \mathrm{hr}$., at average solar radiation intensity of $508.3 \mathrm{~W} / \mathrm{m}^{2}$ for head $0,0.5,1$ and $1.5 \mathrm{~m}$, respectively. While in summer, the average daily pumping discharges were $116.2,101,88.1$ and $80.4 \mathrm{l} / \mathrm{hr}$., at average solar radiation intensity of $782 \mathrm{~W} / \mathrm{m}^{2}$ for heads $0,0.5,1$ and $1.5 \mathrm{~m}$, respectively.

\section{Hydraulic Energy and Pump Efficiency of DSPS}

The variations of hydraulic energy and efficiency of pump for DSPS at different heads and sunlight hours during daylight from 9:00 to 15:00 for three days in winter and summer seasons were shown in Figs. 9 and 10, respectively. From the obtained results, it can be said that, the hydraulic energy and efficiency of pump in head $1.5 \mathrm{~m}$ is the highest one and by decreasing the head until to $0 \mathrm{~m}$, they decreased. Where the hydraulic energy and efficiency is proportional to pumping head. Also, the results revealed that, the hydraulic energy and efficiency were related to a large extent to the solar radiation variations during daylight. 
Zagazig J. Agric. Res., Vol. 46 No. (1) 2019

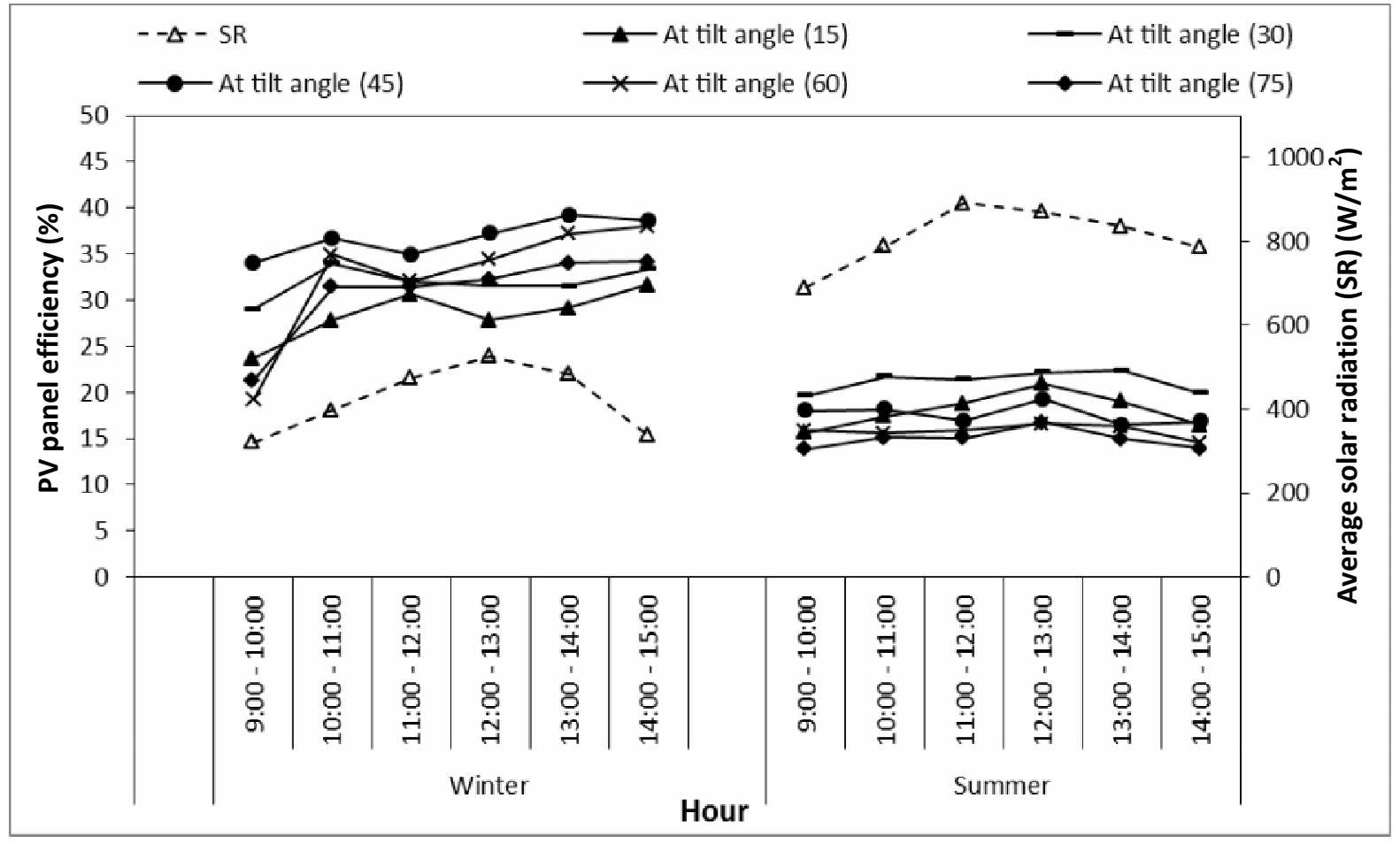

Fig. 6. Effect of tilt angle on PV panel efficiency

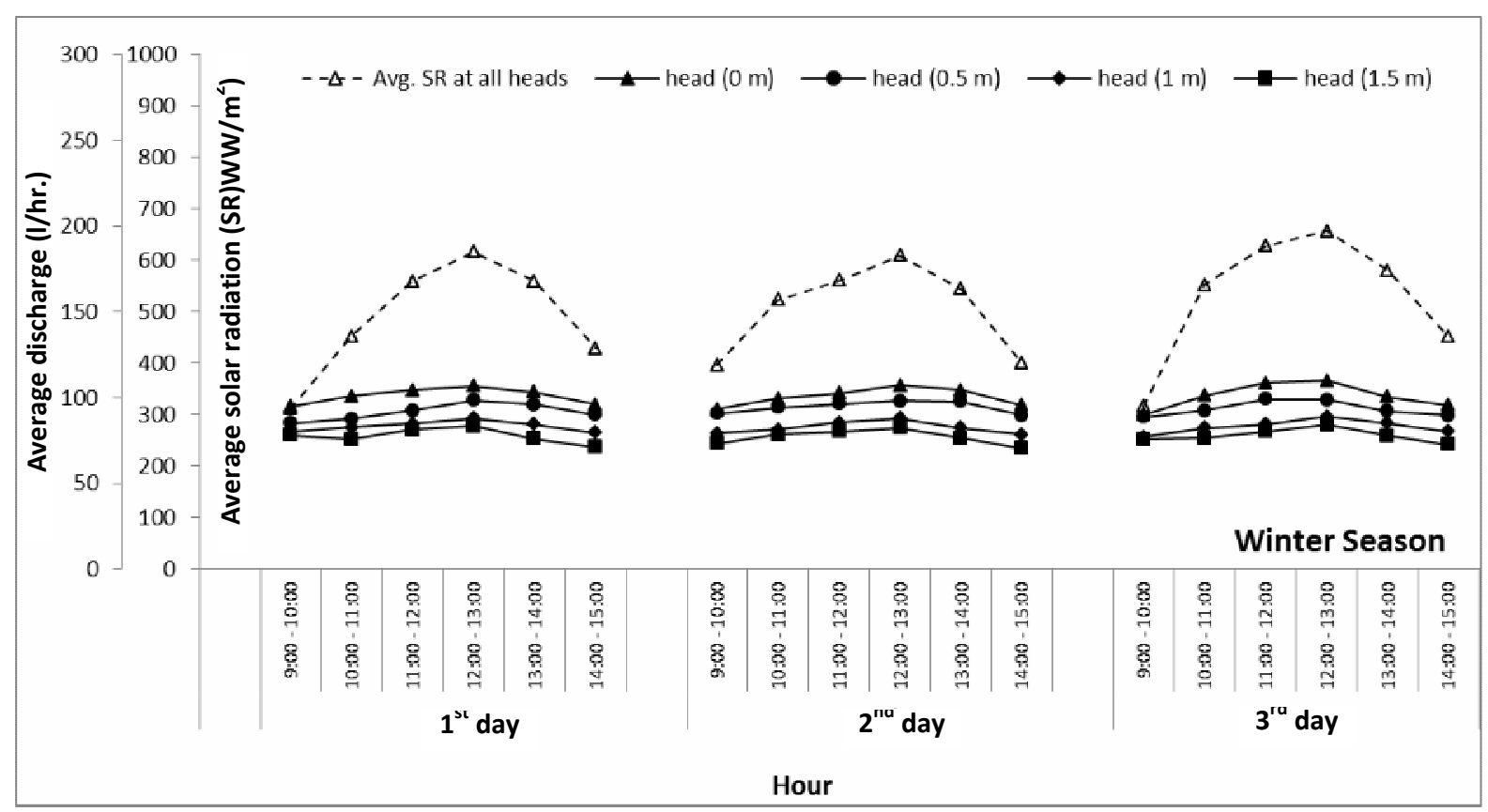

Fig. 7. Effect of solar radiation on pumping of DSPS for different heads in winter 


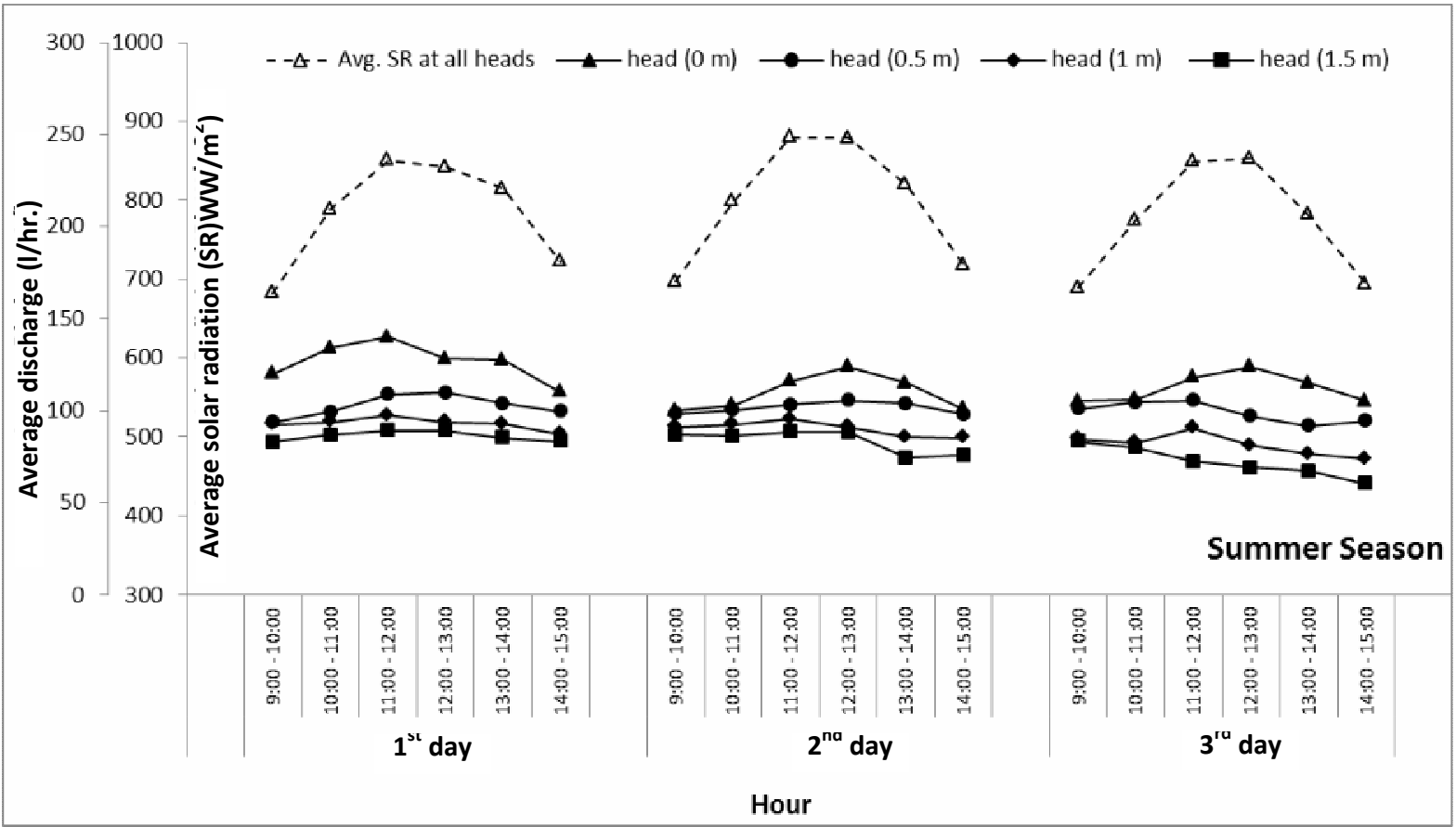

Fig. 8. Effect of solar radiation on pumping of DSPS for different heads in summer

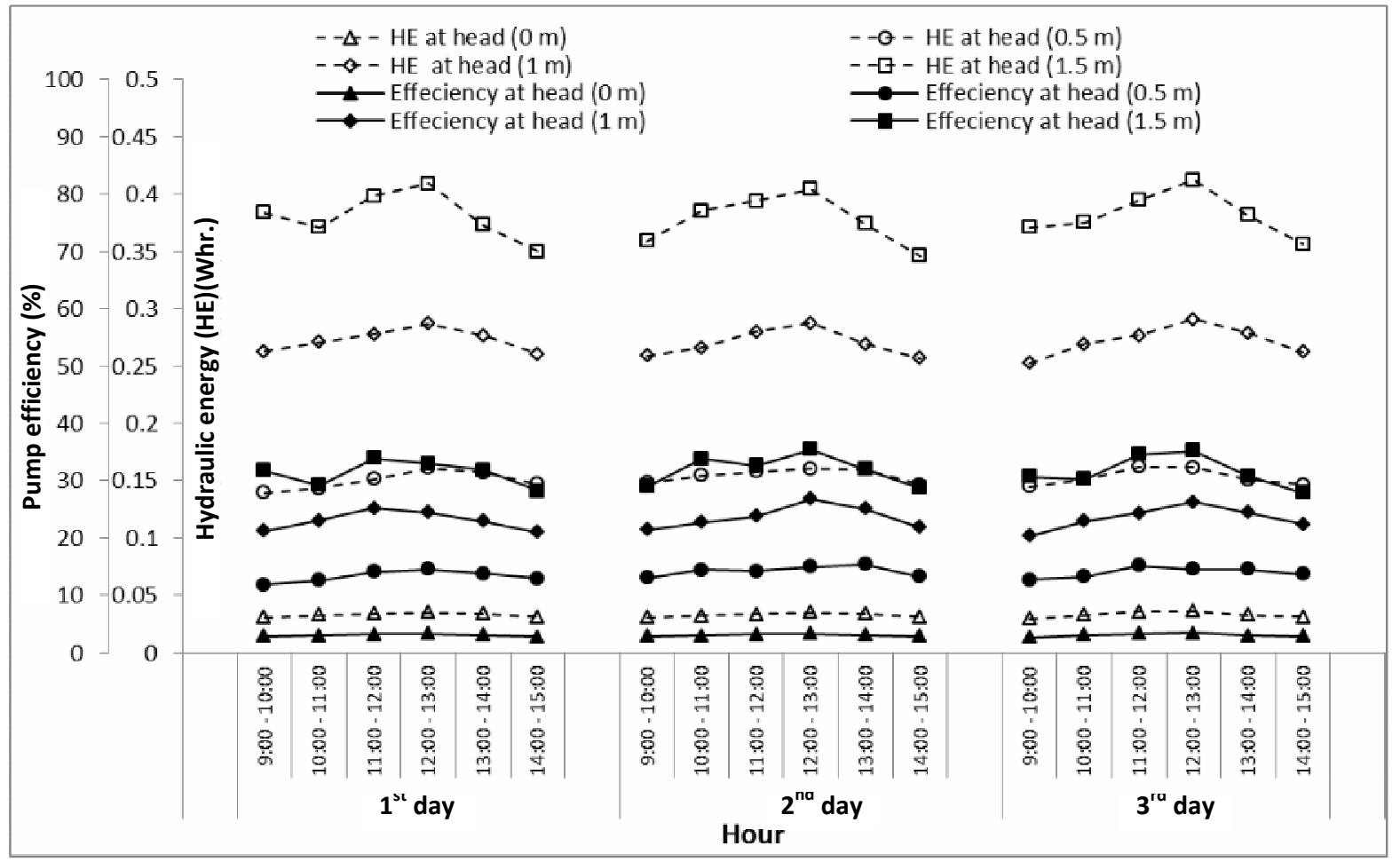

Fig. 9. Variations of hydraulic energy and pump efficiency of DSPS in winter 


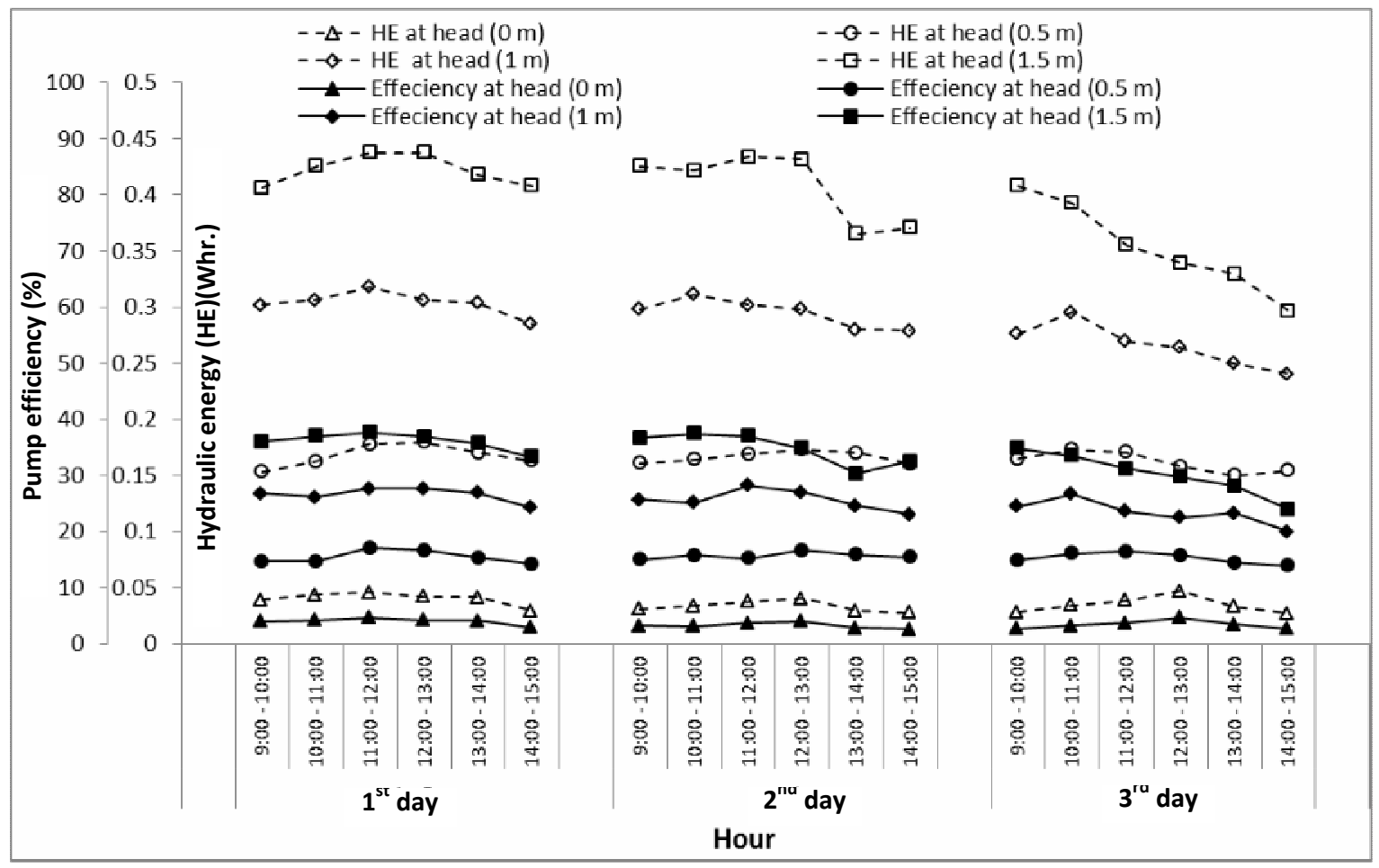

Fig. 10. Variations of hydraulic energy and pump efficiency of DSPS in summer

In winter, the average values of hydraulic energy (for the three days) were $0.03,0.15,0.27$ and $0.38 \mathrm{Wh}$ with pumping efficiency of 3.1 , $13.8,23.4$ and $31.6 \%$ for head of $0,0.5,1$ and $1.5 \mathrm{~m}$, respectively. While in summer, the average values of hydraulic energy were 0.04 , $0.17,0.29$ and $0.4 \mathrm{Wh}$ with pumping efficiency of $3.6,15.5,25.2$ and $33.7 \%$ for head of $0,0.5$, 1 and $1.5 \mathrm{~m}$, respectively.

\section{Pumping Evaluation of ASPS}

In fact, performance pumping of ASPS haven't influenced by the season. This is due to its dependability on battery as a power source for operating of the AC pump. But the charging of battery affected by the solar radiation intensity during winter and summer seasons. So, battery completely charging time was estimated; 180 and 160 minutes at average solar radiation of 536 and $826 \mathrm{~W} / \mathrm{m}^{2}$ for winter and summer season, respectively.

Fig. 11 shows results of the average discharge and hydraulic energy value of AC pump for different pumping heads. These results revealed that, by increasing the pumping head, the discharge decreased but the hydraulic energy increased to reach the peak at $0.5 \mathrm{~m}$ of pumping head then they together decreased after that. At heads of $0,0.5,1$ and $1.5 \mathrm{~m}$, the pumping discharges were $281,140,61$ and $18 \mathrm{l} / \mathrm{hr}$., respectively, while the hydraulic energies were $0.092,0.229,0.2$ and $0.09 \mathrm{Wh}$, respectively. The optimum head can be concluded approximately at $0.25 \mathrm{~m}$ of head from the figure.

\section{Effect of Pumping Head on Both Discharge and Efficiency of the Pump}

The results of the effect of pumping head on both discharge and efficiency of the pump are shown in Fig. 12. Generally, the average efficiencies of both DC (winter and summer) and AC pump increased gradually by increasing of the pumping head vice versa the pumping discharges decreased. For the $\mathrm{AC}$ pump, the average discharge values were $281,140,61$ and $18 \mathrm{l} / \mathrm{hr}$., and the average pump efficiencies were $60,70.4,74.8$ and $79.2 \%$ for pumping heads of $0,0.5,1$ and $1.5 \mathrm{~m}$, respectively. While for DC pump, the average discharge values were 101, 93, 83 and 77 1/hr., with average pump efficiencies of $3.1,13.8,23.4$ and $31.6 \%$ in winter (at average solar radiation of 508.3 $\mathrm{W} / \mathrm{m}^{2}$ ) for pumping heads of $0,0.5,1$ and $1.5 \mathrm{~m}$, respectively; and average discharge values were 


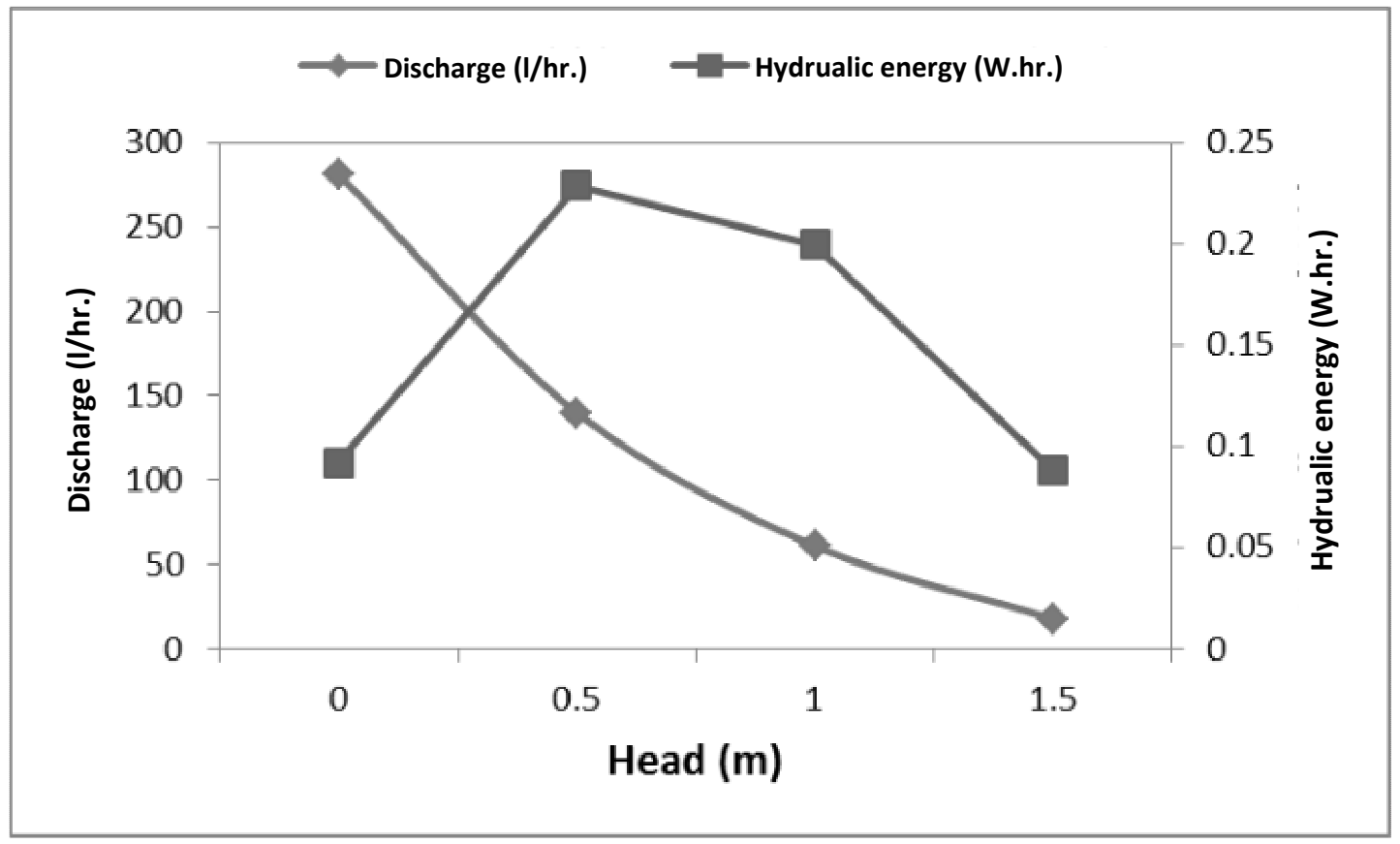

Fig. 11. Average discharge and hydraulic energy of AC pump

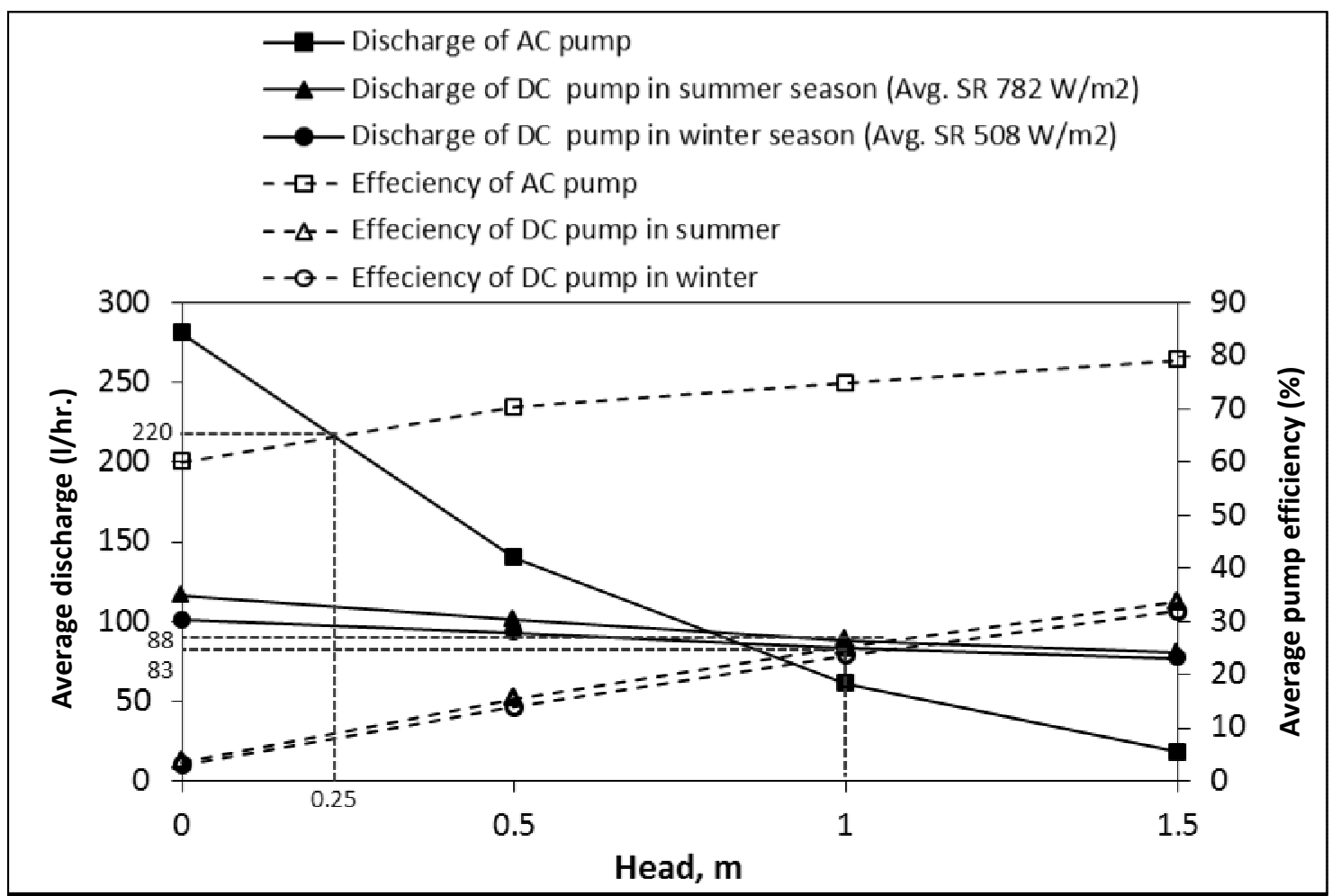

Fig. 12. Effect of pumping head on both discharge and efficiency of the pump 
116, 101, 88 and $801 / \mathrm{hr}$., with average pump efficiencies of $3.6,15.5,25.2$ and $33.7 \%$ in summer (at average solar radiation of 782 $\mathrm{W} / \mathrm{m}^{2}$ ) for pumping head of $0,0.5,1$ and $1.5 \mathrm{~m}$, respectively. From these results, it can be concluded that, the optimum pumping heads could be obtained by crossing the discharge and efficiency lines. So, for the used pump the optimum pumping head was $0.25 \mathrm{~m}$ in case of ASPS (with discharge of $217 \mathrm{l} / \mathrm{hr}$.,) and $1 \mathrm{~m}$ in case of DSPS (with discharges of 83 and 88 $1 / \mathrm{hr}$., for winter and summer seasons, respectively).

\section{Specific Pumping Productivity of Both DSPS and ASPS}

Fig. 13 shows the results of specific pump productivity for both DSPS and ASPS. From the figure it can be concluded that, the pump productivity (function of discharges) was inversely proportional to the pumping head. Where, DSPS produced 9.31, 8.61, 7.66 and $7.15 \mathrm{~m}^{3} / \mathrm{kWh}$ of water pumping during winter;
$10.03,8.72,7.60$ and $6.95 \mathrm{~m}^{3} / \mathrm{kWh}$ during summer, at pumping heads of $0,0.5,1$ and $1.5 \mathrm{~m}$ respectively. While the average pumping productivity of ASPS was about 24.27, 12.09, 4.49 and $0.77 \mathrm{~m}^{3} / \mathrm{kWh}$ at the same heads, respectively.

\section{Cost Estimation of Both DSPS and ASPS}

Fig. 14 shows the results of criterion costs for both DSPS and ASPS. From the figure it can be concluded that, the criterion costs of DSPS was lower than in the ASPS, this is due to the additionally fixed costs of ASPS components included charger controller, battery and inverter. Pumping costs of one cubic meter of water by DSPS at pumping heads of $0,0.5,1$ and $1.5 \mathrm{~m}$, respectively were $(0.16,0.17,0.19$ and 0.21 EGP) and $(0.15,0.17,0.19$ and 0.21 EGP) during winter and summer seasons, respectively. While by ASPS were about $0.22,0.45,1.23$ and $7.11 \mathrm{EGP} / \mathrm{m}^{3}$ at the same heads, respectively.

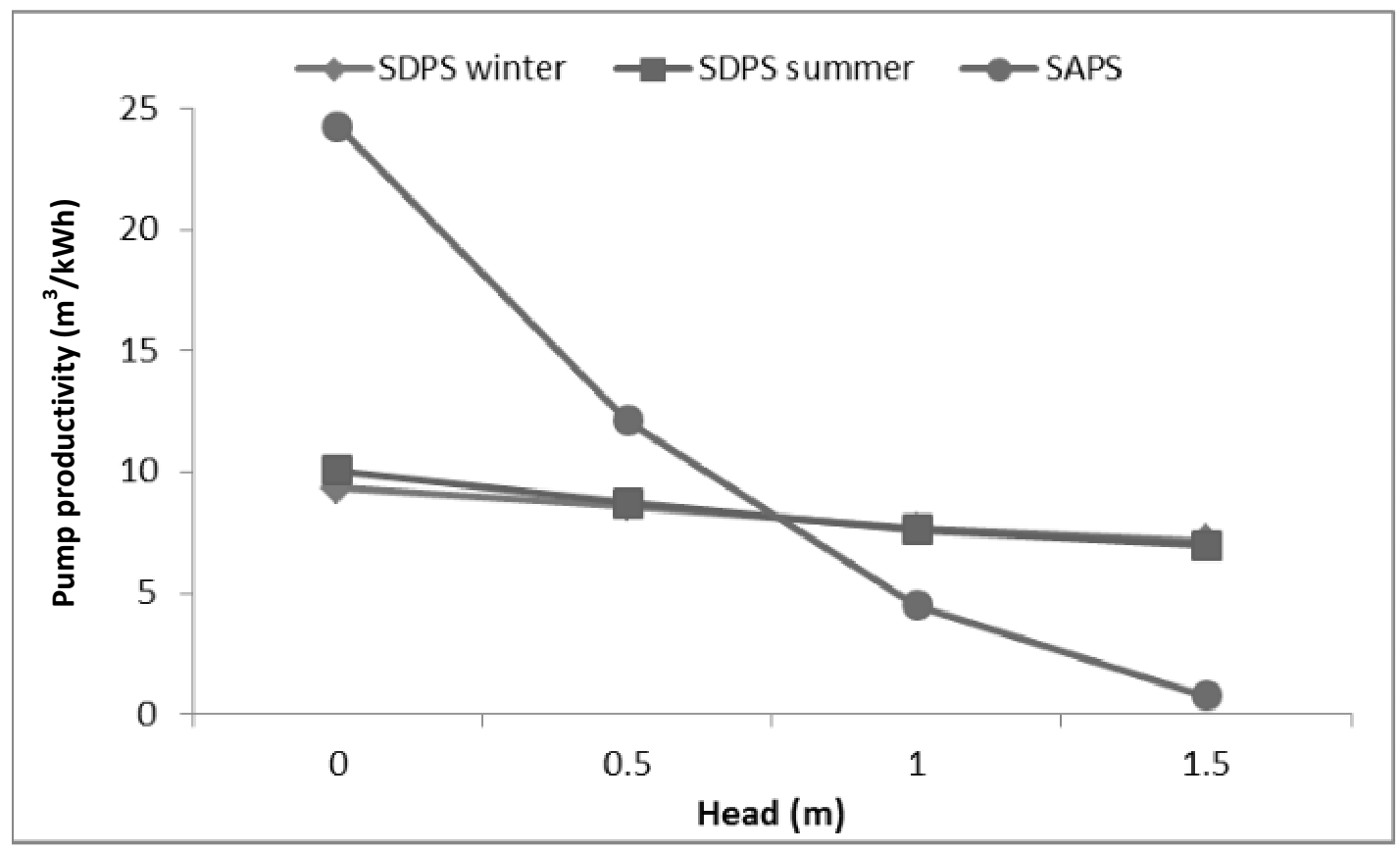

Fig. 13. Specific pump productivity of both DSPS and ASPS 


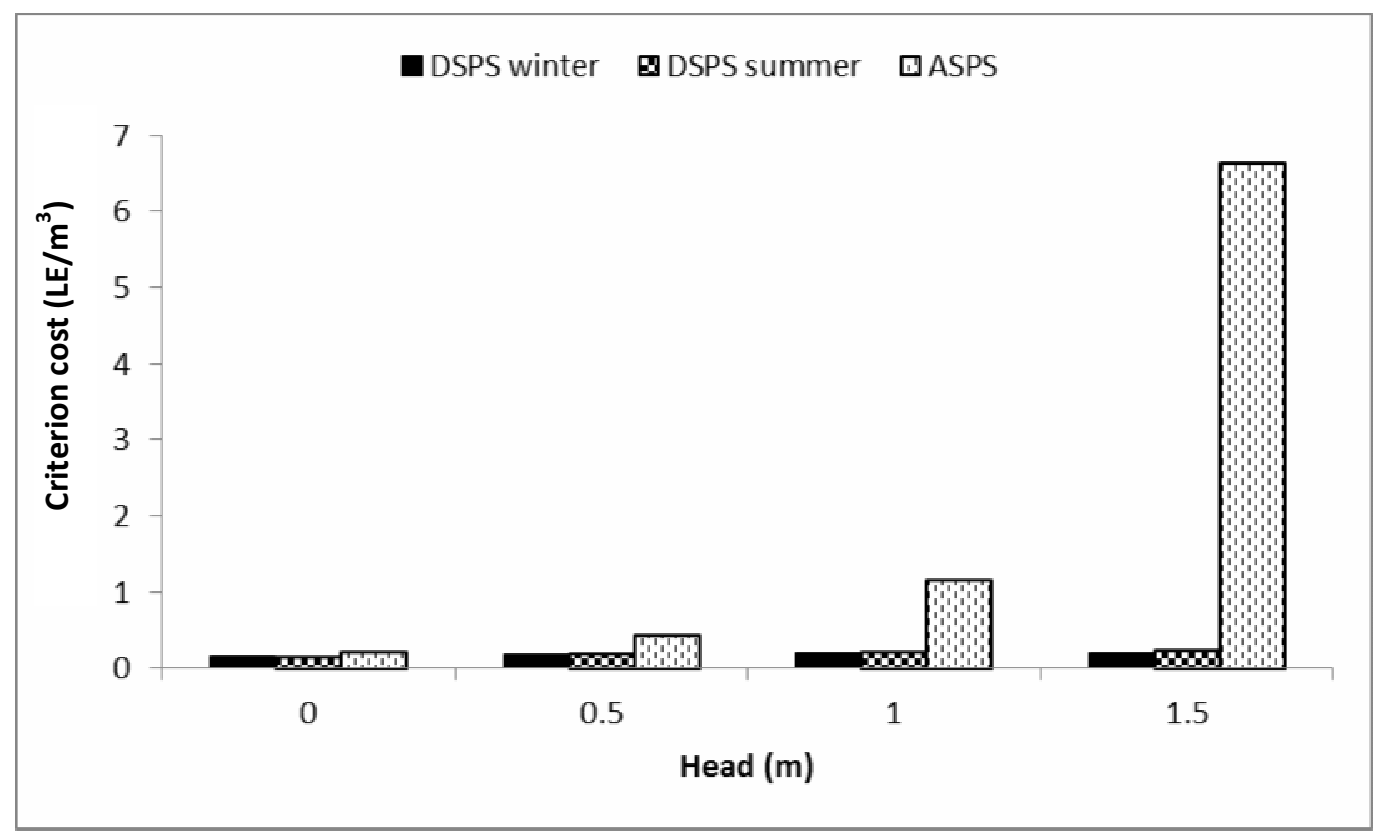

Fig. 14. Criterion cost of both DSPS and ASPS

\section{Conclusion}

From the obtained results, it can be concluded that:

- The small size of solar PV power system (10 Watt) is efficient to operate a small pump (with power of 5 Watt) under the solar radiation conditions of Zagazig District for supplying irrigation water for roof cultivation units.

- The best tilt angle of PV panel for Zagazig District was $45^{\circ}$ and $30^{\circ}$ in winter and summer, respectively.

- Pumping head affects the pumping performance to a large extent.

- Discharges and pumping efficiencies of $\mathrm{AC}$ pumps are higher than DC pumps with the same power.

- The optimum pumping conditions of the used pump (5 Watt) are 0.25 and $1 \mathrm{~m}$ of pumping heads with $220 \mathrm{l} / \mathrm{hr}$., and $(83 \mathrm{l} / \mathrm{hr}$., for winter, $88 \mathrm{l} / \mathrm{hr}$., for summer) of pumping discharge for $\mathrm{AC}$ and $\mathrm{DC}$ pumping systems, respectively.

- One kilowatt in hour by DSPS pumped 9.31, $8.61,7.66$ and $7.15 \mathrm{~m}^{3}$ of water during winter; $10.03,8.72,7.60$ and $6.95 \mathrm{~m}^{3}$ during summer, at heads of $0,0.5,1$ and $1.5 \mathrm{~m}$ respectively. While the average pumping productivity of
ASPS was about 24.27, 12.09, 4.49 and 0.77 $\mathrm{m}^{3} / \mathrm{kWh}$ at the same heads, respectively.

- Pumping costs of one cubic meter of water by DSPS at pumping heads of $0,0.5,1$ and $1.5 \mathrm{~m}$, respectively were $(0.16,0.17,0.19$ and 0.21 EGP) and (0.15, 0.17, 0.19 and 0.21 EGP) during winter and during summer seasons, respectively. While by using ASPS the water pumping costs of $1 \mathrm{~m}^{3}$ were about $0.22,0.45$, 1.23 and $7.11 \mathrm{EGP} / \mathrm{m}^{3}$ at the same heads, respectively.

\section{REFERENCES}

Benghanem, M., K.O. Daffallah, S.N. Alamri and A.A. Joraid (2014). Effect of pumping head on solar water pumping system. Energy Convers Manag., 77 : 334-339.

Chandel, S.S., M.N. Naik and R. Chandel (2015). Review of solar photovoltaic water pumping system technology for irrigation and community drinking water supplies. Renew. and Sustain. Energy Rev., 49: 1084-1099.

Chel, A., G.N. Tiwari and A. Chandra (2009). Sizing and cost estimation methodology for stand-alone residential PV power system, Int. J. Agile Systems and Manag., 4 (1): 21-40. 
Foster, R. and A. Cota (2014). Solar water pumping advances and comparative economics. Energy Procedia, 57: 1431-1436.

Frederick, K.M. (2010). Developing a siteappropriate solar electric powered water pumping system. M.Sc. Thesis, Florida Univ., 44-51.

Gad, H.E. (2009). Performance prediction of a proposed photovoltaic water pumping system at South Sinai, Egypt climate conditions. In: Proc. $13^{\text {th }}$ Int. Water Technol. Conf. Hurghada, Egypt, 739-752.

Gopal, C., M. Mohanraj, P. Chandramohan and P. Chandrasekar (2013).Renewable energy source water pumping systems. Renew. and Sustain. Energy Rev., 25: 351-370.

Guiqiang, L., Y. Jin, M.W. Akram and X. Chen (2017). Research and current status of the solar photovoltaic water pumping system - A review. Renew. and Sustain. Energy Rev., 79: 440-458.

Hamidat, A. and B. Benyoucef (2008). Mathematic models of photovoltaic motorpump systems. Renew Energy, 33 (5): 933942.

Khattab, N., H. Soliman, M. Metias, I. El-Seesy, E. Mettawee, E. El-Shenawy and M. Hassan (2011). Implementation of solar technologies in the development of rural, remote and sub urban communities. Int. J. Thermal and Environ. Eng., 3(2): 59-66.

Narale, P.D., N.S. Rathore and S. Kothari (2013). Study of solar PV water pumping system for irrigation of horticulture crops. Int. J. Eng. Sci. Invent., 2 (12): 54-60.

NREA (2011). New and Renewable Energy Authority Po Annual Report, (2010/2011). Ministry of Electricity and Renew. Energy, Egypt: http: // www. nrea. gov. eg/ Media/ Reports.

NREA (2013). New and Renewable Energy Authority Po Annual Report, (2012/2013): http://www.nrea.gov.eg/Media/Reports.

Said, D., M. Mostafa, K. Youssef and H. Waheed (2017). Highlight of grid-connected PV systems in administrative buildings in Egypt. Renew. Energy and Sustain. Develop., 3 (1): 87-94.

Shinde, V.B. and S.S. Wandre (2015). Solar photovoltaic water pumping system for irrigation: A Rev. Afr. J. Agric. Res., 10 (22): 2267-2273.

Singh, B. and A.K. Mishra (2015). Utilization of solar energy for driving a water pumping system. Int. Res. J. Eng. and Technol. (IRJET), 2 (3): 1284-1288.

Umran, H.M. (2015). Study and analysis for the effects of power factor correction in al-najaf cement plant. Al-Qadisiyah J. Eng. Sci., 8(1): 59-72.

Yingdong, Y., J. Liu, H. Wang and M. Liu (2011). Assess the potential of solar irrigation systems for sustaining pasture lands in arid regions- A case study in Northwestern China. Applied Energy, 88 (9): 3176-3182. 


\title{
تقييم أداء نظام صغير يعمل بـالتيار المتردد/ المستمر لضخ المياه بالطاقة الثمسية لزراعة الأسطح
}

\author{
سـمر علي حسـان - محمد قدري عبدالوهاب ـ أحمد محمد سعدالاين الثال - وسـام السيد عبدالله \\ قسم الهندسة الزر اعية ـ كلية الزر اعة - جامعة الزقازيق ـ مصري
}

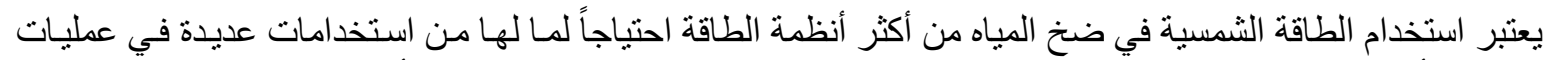

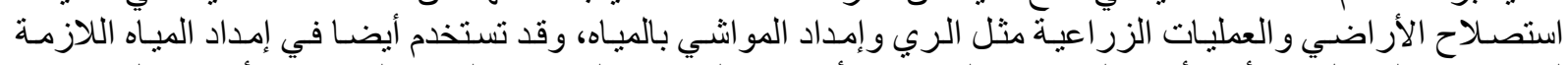

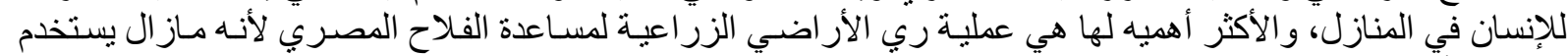

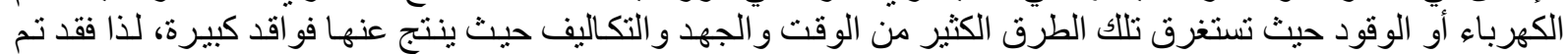

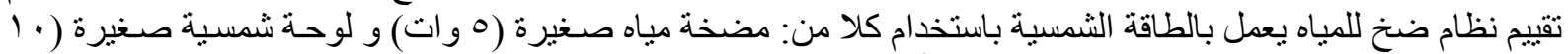

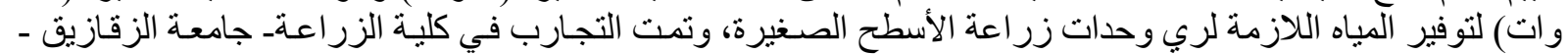

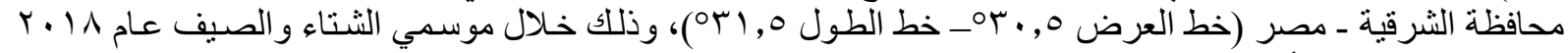

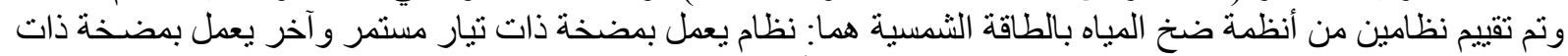

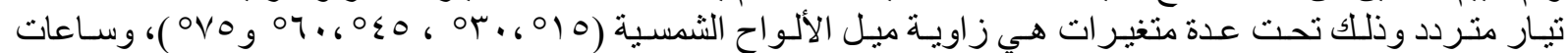

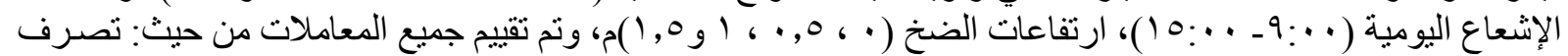

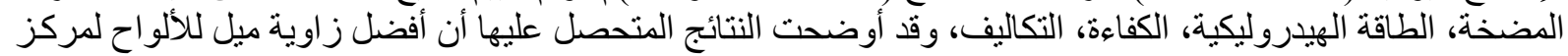

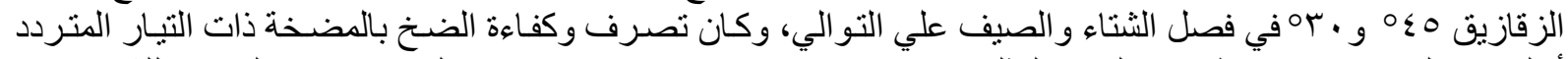

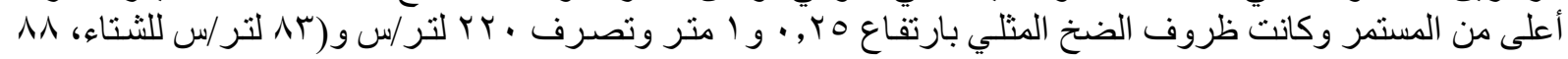

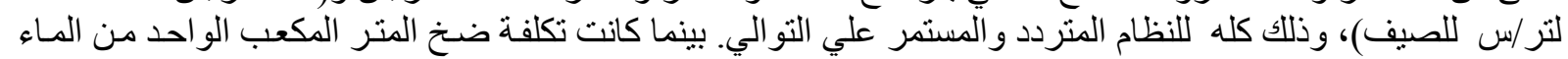

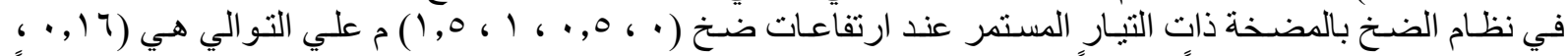

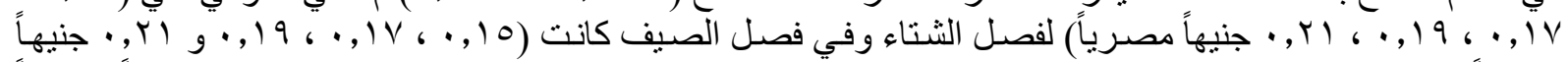

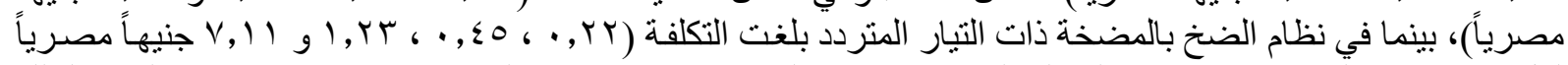

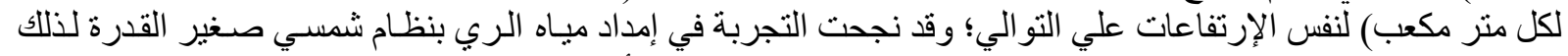

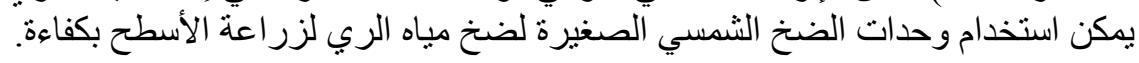

